\title{
Protection of the Environment through State Administrative Law
}

\author{
Imawan Sugiharto ${ }^{1}$, Achmad Irwan Hamzani ${ }^{1{ }^{1 *}}$, Moh. Taufik ${ }^{1}$, Mohamad Khamim ${ }^{1}$ and \\ Havis Aravik ${ }^{5}$
}

${ }^{1}$ Universitas Pancasakti Tegal, 52121, Indonesia

${ }^{2}$ STEBIS IGM, Palembang, 30129, Indonesia

\begin{abstract}
The earth's water and the wealth contained in it are liquidated state to be utilized as much as the prosperity of the people. The state is here to manage nature by paying attention to the environment for the sustainability of development. Climate change, pollution, and environmental damage are threats. Research objectives for the role of the state as the executor of state administrative law, and analyze the basis of state administrative law enforcement in environmental management, as well as the role of the state in the management of natural resources that have an environmental impact. This research uses a normative approach, using secondary data and qualitative data analysis. The results showed that the role of the state as the executor of the duties of administrative law and protection of the environment is mentioned in the 1945 Constitution. The legal basis for enforcement of state administrative law is governed by the Environmental Law, the Energy Act, and the Mining, Minerals, and Coal Act. The function of the state through state administrative law in the management of environmentally impacted energy resources is covered by some of these laws.
\end{abstract}

Keywords: Constitution, law enforcement, state administrative law, environmental damage.

\section{INTRODUCTION}

The earth, water, and wealth contained therein are controlled by the state and used as much as it is for the prosperity of the people. The state has power because it is a mandate of the constitution written in the Constitution of the Republic of Indonesia Year 1945. The management of natural resources should pay attention to the ecology of the environment so that the sustainability of natural benefits can be felt from generation to generation. The state has a responsibility to maintain the environment as well as possible so that the sustainability of development runs well. The construction of the 1945 Constitution mandates that natural resources be used for the greater prosperity of the people. This prosperity should be enjoyed by current and future generations (Mukhlish, 2010). Awareness of the importance of environmental issues and the possibility of public participation of both citizens and non-governmental organizations (NGOs) is very important (Beyer, 2006). Local stakeholders, both private landowners, managers, communities, entrepreneurs, and non-governmental organizations often have fundamentally different values and aspirations related to the environment (Appelstrand, 2012).

The issue of the environment received serious attention when the UN Economic and Social Council conducted a review of the results of the "1960-1970 World Development Decade" Movement to formulate

*Address correspondence to this author at the Universitas Pancasakti Tegal, 52121, Indonesia; E-mail: al_hamzani@upstegal.ac.id the second World Development Strategy (1970-1980). The UN General Assembly accepted the offer of ideas about the environment and held a UN Conference on the Human Environment in Stockholm in June 1972 (As'adi, 2019). This conference became an important initial issue felt by all countries of the world. Countries of the world began to view environmental issues as critical to the safety of mankind (Johnson, R.C., Snider, B. N., \& Smith, 1994). Included in the case of disclosure of social responsibility relating to interactions between the organization and its physical and social environment (Deegan \& Rankin, 1996).

The problem is also felt by Indonesia as a developing country in understanding and managing the environment as a substantial thing. Indonesia as a country with a large population at least has problems. First, a large population with low land carrying capacity. Second, the rapid rate of population growth coincides with the rapid rate of environmental damage. Third, the growing insistence on the need for high economic growth to meet basic needs.

The decline in environmental quality in the last five years is increasingly concerning. Before the reforms rolled in, the environmental management system was already effective. Changes in the social, economic and political order, accompanied by changes in the system of government from centralistic to autonomy undermine the role of the central government in the preservation of the environment. This weakening caused environmental management to occur many violations of rules and regulations on the preservation of life, both at the policy level up to the level of programs and 
activities. As a result of the quality of the environment also decreases so severely that the quality of life reaches a level that endangers human life.

Environmental issues are the responsibility of the state to address them. According to Stefanie Beyer (2006), the foundation of effective environmental protection is the legal regime of a country and its implementation. The presence of state administrative law is to provide fresh angina, in which the state can intervene in every public affair. This is to maintain order, legal certainty, justice, and its benefits in supporting the life and activities of every human being as an individual or as a member of society. These government intervention efforts accordingly include the regulation of means for the authorities to take care of and control the community, the regulation of the way citizens participate in the process of regulation and control, and the regulation of legal protection (rechtsbescherming) (Fahmal, (2006).

The issue of environmental handlers required legal development that must be carried out continuously and comprehensively, especially oriented environmental sustainability. It is expected that the legal output will not be left behind by the dynamics of society in the future. Moreover, the legal position is very important in solving environmental problems (Handoyo, 2017).

This study will discuss the protection of the environment through state administrative law. Issues that will be studied are legal protection in a rule of law, the legal basis for managing energy resources with environmental impacts, and managing energy resources with environmental impacts from the perspective of state administrative law.

\section{RESEARCH METHODS}

The approach used in this study is normative. The normative approach in legal research is to examine legal issues with a positive legal perspective. This research uses a normative approach because it examines environmental protection based on applicable laws and regulations, namely state administrative law. The data source used by this research is secondary data. Secondary data is data obtained indirectly or has been provided by other parties. Secondary data used in the form of legal documents that are used as the main reference to review environmental protection perspectives of state administrative law. Data collection techniques used in this study through offline and online investigation.
Offline library smoothing is the activity of finding the source of the library to the data store. While online graduation is the activity of finding library sources in cyberspace through the internet network. Conventional library graduation is done by looking for library materials to libraries, collections of books and personal journals, purchasing books, and visiting scientific activities (seminars). While online smoothing is done by searching the internet. The data analysis method used is qualitative. Qualitative data analysis is the process of organizing and sorting data into patterns, categories, and units of the basic description so that themes can be found presented in the form of narratives (Hamzani, 2020). This research uses qualitative data analysis because the data will be presented narrativelydescriptively, not in the form of numbers or numerical.

\section{DISCUSSION}

\section{Legal Protection in the Rule of Law}

The state of the law has principles that must be met. Experts formulated several principles in the state of law namely the principle of legality, protection of human rights, the government tied to the law, the right to force the government in law enforcement, and independent judges (Hamzani, 2015).

The law is placed as a rule of play in the administration of the state, government, and society. The purpose of the law itself is to organize a peaceful, just, and meaningful society. The goal of the state law is the creation of state, governmental, and community activities that rely on justice, peace, and benefit or meaning. Legal existence is used as an instrument in organizing the life of the state, government, and society in the state of law. The main goal is to create an orderly society, create order, and balance (Handoyo, 2017).

As a tool, the law is a rule that can prevent the ruler from acting arbitrarily. The law is the limits of freedom between individuals and rulers in every interaction until the law becomes protection and guarantee against the creation of general tranquility. Without the law, there will be chaos and arbitrariness. Vivian Bose reveals that the law is the property of all humanity (the rule of law is the heritage of all mankind). Its implementation lies in the limitation of power to prevent absolutism leading to "onregmatigedaad" even resulting in the act of "ongrondwetting" (contrary to the Constitution) (Thahira, 2020).

There are five legal functions in people's lives. First, directive or as a director in building to form a society to 
be achieved under the purpose of state life. Second, integrative as the builder of national unity. Third, stability is as a caretaker (including the results of development) and custodian of harmony, harmony, and balance in the life of the state and society. Fourth, effective as a refiner to the actions of the state administration, as well as the attitude of citizens in the life of the state and society. Fifth, corrective that is both against citizens and state administration in obtaining justice. As a welfare state, the government's duty to conduct the public interest is very broad. It is necessary to have the flexibility to move in the administration of the state under the authority given. So broad is the function of state administration in the welfare state so that the wider the field of duty carried out. It is difficult to imagine a modern state today without the existence of state administrative law (Hafidz, 2012).

The implementation of government and state duties in a legal state has the rule of law written in the constitution or regulations compiled in the law of the state. However, for the implementation of technical issues, the constitutional law is not fully implemented effectively. Constitutional law requires other laws of a technical nature. The law is the state administrative law. Given that the country is an organization of power (machtenorganisatie), then eventually the law of state administration will appear as an instrument to oversee the use of government power. The existence of state administrative law arises because of the implementation of state and government powers in a legal state, which demands and requires the implementation of state, government, and community duties based on the law (Nasarudin, 2016).

The existence of state administrative law in the context of environmental law is very important because it is very influential on law enforcement in environmental law that prioritizes the enforcement of administrative law based on several reasons:

a. serves as a means of controlling, preventing, and repeating prohibited acts;

b. juridical instruments of administrative law that are preventive and serve to end or stop environmental violations;

c. is repairman (restoring to its original state);

d. administrative sanctions do not need to go through a long-lasting court process;

e. as a means of prevention can be more efficient from the point of financing and settlement time than the enforcement of criminal and civil law; and

f. administrative law enforcement costs are cheaper than criminal and civil law (Ambarsari, 2020).

Enforcement of environmental law can be done preventively and repressively, under its nature and effectiveness (Syaprillah, 2016). Although voices are suggesting that law enforcement through administrative law can cause arrest problems (collusion between regulators and regulated) and error charges are too high (because evidentiary standards are much lower than criminal law) (Faure \& Svatikova, 2012).

The presence of the state in the conception of the environment can be seen constitutionally, especially in the opening of the 1945 Constitution of the fourth paragraph, that the state must protect the entire nation of Indonesia and the entire spilt blood of Indonesia, promoting the general welfare; educate the life of the nation and participate in implementing world order based on independence, lasting peace and social justice for all of Indonesia. The description of the presence of the state is mandated by the basic constitution of the state of Indonesia, namely article 33 which reads:

a. the economy is structured as a joint venture based on family principles;

b. the branch of the production branch that is important to the state and which controls the lives of many people controlled by the state;

c. the earth and water and the natural wealth contained therein are controlled by the state and used for the greater prosperity of the people; and

d. the national economy is organized based on the principle of economic democracy with the principles of togetherness, efficiency, justice, sustainability, environmentally sound, selfreliance, and by maintaining the balance of progress and national unity (Ruslina, 2012).

Contrary to the mandate of the constitution, it can be understood that the state is the sole ruler of the earth, water, and natural resources in all regions of the Unitary Republic of Indonesia. The function of the state, in this case, becomes the authority of the government as the holder of state power, as well as to the right to control over the earth, water, and natural 
resources including the management of energy sources and other natural resources that have an impact on the environment.

This conception refers to the economic concept of Pancasila, which is a system that is dug up and built from the values embraced in the Indonesian society. Some of the basic principles are related to the principles of humanity, economic nationalism, economic democracy embodied in the populist economy, and justice (Umam, 2017).

\section{Legal Basis for Environmental Impact Energy Resources Management}

The development of environmental law in Indonesia was born since the enactment of the Law of the Republic of Indonesia Number 4 the Year 1982 concerning Basic Provisions of Environmental Management. The law was replaced by the Law of the Republic of Indonesia Number 23 the Year 1997, and finally the Law of the Republic of Indonesia Number 32 the Year 2009 concerning Environmental Protection and Management.

Environmental law has provided a very strong legal basis for protecting the community to avoid poor environmental quality and including environmental disputes (Wijoyo, 2013). Environmental law is a field of law called the field of functional law, namely a field of law containing the provisions of state administrative, criminal, and civil law. If observed, environmental law clouds the norms of laws that go into the field of state administrative, criminal, and civil law.

The government also issued several related laws to realize the presence of the state in energy and environmental management and to improve the welfare of the community. Some of these laws are in the contractor of the Law of the Republic of Indonesia Number 30 the Year 2007 concerning Energy, and the Law of the Republic of Indonesia Number 4 the Year 2009 concerning Mineral and Coal Mining.

Environmental law responds to the demands of environmental activists so that the state can be present in the issue of the environment, which in the future needs attention and seriousness. In addition to the principles, objectives, and scope of environmental protection, also explained the various rules of the preparation of environmental protection and management plans at the national, provincial, and district/city levels. Any business about environmental impact must also complete the requirements for environmental impact analysis.
It is explained in environmental law about the obligation of governments and local governments to make strategic environmental studies to ensure that the principles of sustainable development. The results of environmental studies should serve as the basis for policies, plans, and/or development programs in a region. Environmental law is the main formal source of environmental law in Indonesia in addition to containing legal provisions and legal instruments. Some important new legal norms are about the protection of the law on everyone who fights for the right to the environment, the authority of the Civil Servant Investigative Officer, and the creation of new material deliberations.

First, environmental law has explicitly adopted the principles contained in the 1992 Rio Declaration, namely the principles of state responsibility, integration, prudence, justice, pay polluters, participatory and local wisdom. This adoption is an important legal politics because it can strengthen the interests of environmental management while dealing with shortterm economic interests. Judges in adjudicating a case can use those principles to pay attention to the interests of environmental management that may not be noticed by businesses or authorized government officials.

Second, environmental law is very advanced in providing legal protection to people who fight for the right to the environment from possible criminal and civil charges. Legal protection is very important because in the past there have been cases where environmental activists who reported allegations of environmental pollution and destruction have been sued civilly or criminally prosecuted by companies suspected of causing environmental destruction. The legal system of the United States and the Philippines governs the guarantee of such legal protections as the Strategic Legal Action Against Public Participation. It means guarantees against lawsuits made by companies that are alleged to have damaged the environment and then sue the whistleblower or whistleblower to cause fear and material harm (Aji, et al., 2020). The counterlawsuit turns off the courage of members of the public to be critical and to submit reports or information about allegations or environmental problems by the business sectors. Finally, it can thwart environmental management that involves the active role of civil society (civil society). Judges in Indonesia are very important to understand the presence and usefulness of environmental protection.

Third, environmental law has led to changes in the field of investigative authority in environmental matters. 
Based on Article 6 paragraph (1) of the Criminal Proceedings Code (KUHAP), investigators are officials of the State Police of the Republic of Indonesia and certain Civil Servant Officials who are specially authorized by law. Environmental law is one of the laws as referred to in Article 6 paragraph (1) which becomes the basis for the existence of Civil Servant Officers as formulated in the Article of Authority of the Police of the Republic of Indonesia other than as stated in Article 7 paragraph (1) of the Criminal Code, namely making arrests, detentions, searches, and seizures, examination, and seizure of letters and coordinating authorities for the implementation of duties as authorized institutions to submit case files to the public prosecutor.

Law of the Republic of Indonesia Number 30 the Year 2007 concerning Energy consists of 34 articles explaining energy regulation, management of environmental and community impacts. Besides, the Establishment of the National Energy Council to make national energy policy and supervise the implementation of energy policy. While the Law of the Republic of Indonesia Number 4 the Year 2009 concerning Mineral and Coal Mining consists of 175 articles that explain and regulate the territory of mining businesses, people's mining areas, mining business licenses, mineral, and non-mineral mining management and the rules for the expiration of mining business licenses that can be revoked if they violate the provisions.

\section{Management of Energy Resources with Environmental Impact in the Perspective of State Administration Law}

The role of the state that gets the mandate of the constitution is understood that the sole sovereign state over the earth, water, and natural resources that exist throughout the territory of Indonesia. But this role is not only to create general welfare but also as one of the preventive measures in reducing environmental damage as an impact of economic development.

The construction of infrastructure sources of energy production sources, both in the form of oil refineries, construction of geothermal power, nuclear power plants, undoubtedly have environmental impacts around it. The implementation of environmental impact control requirements applies not only to infrastructure development that can have an important impact on the environment but the impact of waste that arises in the process of managing and processing energy production sources.
The role of the state in the Management of Energy Resources with Environmental Impact can be seen in the articles in the Law of the Republic of Indonesia Number 32 of 2009 . This is the duty of the state that is included in the legal consequences of state administration, which takes the role of interfering in public affairs to provide legal protection in terms of legal certainty, justice, and benefit. At the same time as a systematic and integrated effort is carried out to preserve the function of the environment and prevent the occurrence of pollution and/or environmental damage that includes planning, utilization, control, maintenance, supervision, and law enforcement (Mina, 2016).

Several articles related to the role of the country as the duty of implementing state administrative law as stipulated in the Law of the Republic of Indonesia Number 32 the Year 2009 concerning Environmental Protection and Management, among others as follows:

First, Article 1 paragraph (35). An environmental permit is a license granted to everyone who conducts business and/or activities that must be analyzed on environmental impacts in the framework of environmental protection and management as a prerequisite for obtaining a business license. Both the central and local governments are entitled to issue permits for any business entity that will open or set up a factory (Mina, 2017). With this mechanism, the presence of the state can provide preventive measures in environmental protection.

Second, Article 19. To maintain the sustainability of environmental functions and public safety, each regional spatial planning must be based on environmental studies in the form of evaluation of regional spatial plans, long-term and medium-term development, as well as policies and programs that have the potential to cause impacts or risks to the environment. Spatial planning of the area is determined by paying attention to the carrying capacity and tamping capacity of the environment. Business management that has an environmental impact should look at the spatial concept that has been set by the government. There are green, yellow, and red zones that must be implemented so that the implementation of development that has an environmental impact can maintain environmental conservation well.

Third, Article 22. Any business and/or activity that has an important impact on the environment must have an analysis of environmental impacts. Important impacts are determined based on the criteria: 
a. the number of people who will be affected by the business plan and/or activities;

b. the area of impact distribution;

c. intensity and duration of impact;

d. the number of other environmental components that will be affected;

e. cumulative properties of impacts;

f. reverse or and/or not reverse the impact; and

g. other criteria for the development of technological science under knowledge.

Every business entity that will carry out activities of an economic nature is primarily a requirement to obtain an analysis permit on environmental impacts. The aim is to ensure that the place of business to be established is safe and maintained environmental interests. Often some people use special or fast lines in managing the analysis of environmental impacts, ultimately causing problems. The presence of smoke from forests that disturb not only the people of Indonesia, but also neighboring countries, by landowners who do not have an analysis of environmental impacts, will cause harm to the state, the image of the Indonesian state, and worse is systemic environmental damage.

Fourth, Article 23. Important business criteria and/or activities that must be equipped with an analysis of environmental impact consists of;

a. changes in the shape of land and landscapes;

b. exploitation of natural resources, both renewable and non-renewable;

c. processes and activities that could potentially cause environmental pollution and/or damage as well as waste and waste of natural resources in their utilization;

d. processes and activities whose results can affect the natural environment, artificial environment, as well as the social and cultural environment;

e. processes and activities whose results will affect the preservation of natural resource conservation areas and/or the protection of cultural reserves;

f. introduction of plant species, animals, and bodies; g. manufacture and use of biological and nonbiological materials;

h. activities that have a high risk and or affect the defense of the state; and

i. the technology that is estimated to have great potential to affect the environment.

This article describes the business criteria that have an important impact on the management of environmental impact analysis to maintain the environmental sustainability. The state helps provide services in environmental law.

Fifth, Article 34. It is stated that any business and/or activity that is not included in the criteria for mandatory analysis of environmental impacts such as. The governor or regent/mayor determines the type of business and/or activity that must be equipped with a permit. This article regulates that business entities that do not require the manufacture of Amdal are carried out by local governments, both provincial and district.

Sixth, Article 35. Businesses and/or activities that are not required to be equipped with a permit and must make a statement of the ability to manage and monitor the environment. Determination of business types and/or activities is carried out based on the criteria: not included in the category of important impacts, and micro and small business activities.

Seventh, Article 36. It is mentioned that:

a. every business and/or activity that must have an analysis of environmental impacts or must have an environmental permit;

b. environmental permits are issued based on environmental feasibility decisions;

c. environmental permits are required to include the requirements contained in environmental feasibility decisions or recommendations; and

d. environmental permits are issued by the Minister, Governor, or Regent/Mayor under their authority.

Eighth, Article 37. It is stated that the Minister, Governor, or Regent / Mayor under his authority must reject the application for environmental permits if the permit application is not equipped with an analysis of environmental impacts. Environmental permits as may be revoked if: 
a. the requirements submitted in the permit application contain legal defects, errors, misuse and untruths and/or falsification of data, documents, and/or information;

b. its issuance without eligibility as stated in the commission's decision on environmental feasibility; and

c. the obligations stipulated in the environmental impact analysis document are not carried out by the person in charge of the business and/or activity.

Broadly speaking, The Law of the Republic of Indonesia Number 32 the Year 2009 concerning Environmental Protection and Management focus on administrative requirements, the spatial arrangement of regions, determination of licensing criteria for business entities that use environmental impact analysis for business entities that have important impacts. Besides, it also issues environmental permits and rejects environmental permit applications. All to create the role of state administrative law in realizing laws that provide justice, legal certainty, and benefits for the environment.

The functional meaning of the existence of environmental licensing in the context of environmental management supervision that refers to environmental law is based on the realization of sustainable development. This as an effort to control environmental pollution and destruction is reflected in the comprehensive level of permit requirements (Mukhlish, 2010). Through the tool of licensing requirements that environmental licensing instruments have an important meaning in the framework of the prevention of environmental pollution and to assess the performance of environmental management of a company. There are environmental licensing requirements that accommodate all forms of basic components of protection, which in this case include the following requirements:
a. standard condition;
b. limit condition;
c. operating condition;
d. monitoring requirements; and
e. reporting condition.

The concept of licensing requirements mentioned above is part of the substance of the development of the existing environmental licensing system in Indonesia towards an integrated environmental licensing (Mukhlish, 2010). Philosophically, a good and healthy environment is the human right of every Indonesian citizen guaranteed by the 1945 Constitution, which can only be achieved by holding economic development based on the principles of sustainable and environmentally sound development. Such legal political thinking is in line with the principles of sustainable and environmentally sound development agreed in international declarations and treaties through the UN conference on Environment and Development.

\section{CONCLUSION}

Based on the above discussion, it can be concluded that legal protection in Indonesia is stated in the 1945 Constitution. The legal basis for environmental-based natural resource and energy management is Law of the Republic of Indonesia Number 32 of 2009 concerning Environmental Protection and Management, the Law of the Republic of Indonesia Number 30 the Year 2007 concerning Energy, and the Law of the Republic of Indonesia Number 4 the Year 2009 concerning Mineral and Coal Mining. Environmental law guarantees the functioning of the state through state administrative law in the management of environmentally impacted energy resources covered in several articles. Mentioned in Article 1 concerning the issuance of environmental permits as a prerequisite for obtaining businesses and/or activities, Article 19 to maintain environmental sustainability, Article 22, Article 23, 34 of the license to analyze environmental impacts for every business and/or activity has an important impact on the environment, Article 23 on business criteria and/or activities has an important impact, Article 35 on businesses and/or activities that are not obliged to be equipped with an analysis of environmental impacts, Article 36, 37 and Article 38, 39, 40 on any business and/or activity that must have an analysis of environmental impacts.

\section{ACKNOWLEDGEMENTS}

The author would like to thank the Faculty of Law Universitas Pancasakti Tegal for providing funding for this research in 2020. All authors contributed to this research according to their respective assignments.

\section{REFERENCE}

Aji, A.B.W., P. Wiyatno, R. Arifin, U. Kamal, (2020). Social Justice on Environmental Law Enforcement in Indonesia: The 
Contemporary and Controversial Cases. The Indonesian Journal of International Clinical Legal Education, 2, (1), 5772.

https://doi.org/10.15294/ijicle.v2i1.37324

Ali, Z. (2019). Metode Penelitian Hukum. Jakarta: Sinar Grafika

Ambarsari, N. L. M. A. H. N. (2020). Penegakan Hukum Administrasi Lingkungan Melalui Instrumen Pengawasan: Rekonstruksi Materi Muatan Undang-Undang Nomor 32 Tahun 2009 Tentang Perlindungan Dan Pengelolaan Lingkungan Hidup. Al'Adl, 12, (1), 116-130. https://ojs.uniskabjm.ac.id/index.php/aldli/article/view/2650

Appelstrand, M. (2012). Developments in Swedish Forest Policy and Administration-From A "Policy of Restriction" Toward A "Policy of Cooperation. Scandinavian Journal of Forest Research, 27, (2), 186-199. https://doi.org/10.1080/02827581.2011.635069

As'adi, E. (2019). Hukum Administrasi Negara Dalam Pengelolaan Sumber Daya Alam dan Energi Berbasis Lingkungan. Jakarta: Raja Grafindo Persada.

Beyer, S. (2006). Environmental Law and Policy in the People's Republic of China. Chinese Journal of International Law, 5 (1), 185-211. https://doi.org/10.1093/chinesejil/jmk002

Deegan, C., \& Rankin, M. (1996). Do Australian Companies Report Environmental News Objectively?: an Analysis of Environmental Disclosures by Firms Prosecuted Successfully by the Environmental Protection Authority. Accounting, Auditing \& Accountability Journal, 9, (2), 50-67. https://doi.org/10.1108/09513579610116358

Fahmal, M. (2006). Peran Asas-Asas Umum Pemerintahan yang Layak dalam Mewujudkan Pemerintahan yang Bersih. Yogyakarta: UII Press.

Faure, M. G., \& Svatikova, K. (2012). Criminal or Administrative Law to Protect the Environment? Evidence from Western Europe. Journal of Environmental Law, 24, (2), 253-286. https://doi.org/10.1093/jel/eqs005

Hafidz, J. (2012). Malfungsi HAN dan Upaya Melakukan Rekonstruksi Sistem Hukum yang Ada Menuju Hukum yang Melayani. Jurnal Hukum Fakultas Hukum Unissula, 28, (2), 841-860. https://doi.org/10.26532/jh.v28i2.216

Hamzani, A.I. (2020). Towards Indonesia as a State Law be Happiest People. International Journal of Business, Economics and Law, 6 (4), 152-157. https://www.ijbel.com/previousissues/april-2015/vol-6-issue-4-april-2015-law/

Hamzani, A.I., F. D. Aryani, H. Aravik. (2020). The Trend to Counter Terrorism in ASEAN. Journal of Advanced Research in Dynamical and Control Systems, 12, (7), 105-113. https://doi.org/10.5373/JARDCS/V1217/20201990

Handayani, R. Edi As'adi, (2016). Pengelolaan Sumber Daya Energi Berbasis Lingkungan dalam Rangka Mewujudkan Negara Kesejahteraan. Jurnal Hukum lus Quia lustum, 24, (1), 94112. https://doi.org/10.20885/iustum.vol24.iss1.art5
Handoyo, B. (2017). Legalitas Lingkungan Hidup dalam Perspektif Keadilan dan Hukum Administrasi Negara. AL-IJTIMA \%: International Journal of Government and Social Science, 2, (2), 173-188. https://journal.ar-raniry.ac.id/index.php/jai/ article/view/470

Johnson, R. C., Snider, B. N., \& Smith, D. L. (1994). The Deaf Way: Perspectives from the International Conference on Deaf Culture. Gallaudet University Press.

Law of the Republic of Indonesia Number 30 of 2007 concerning Energy.

Law of the Republic of Indonesia Number 32 of 2009 concerning Environmental Protection and Management.

Law of the Republic of Indonesia Number 4 of 2009 concerning Mineral and Coal Mining.

Mina, R. (2016). Desentralisasi Perlindungan dan Pengelolaan Lingkungan Hidup Sebagai Alternatif Menyelesaikan Permasalahan Lingkungan Hidup. Arena Hukum, 9, (2), 149162.

https://doi.org/10.21776/ub.arenahukum.2016.00902.1

Mina, R. (2017). Pelaksanaan Izin Lingkungan di Kabupaten Banggai sebagai Upaya Perlindungan dan Pengelolaan Lingkungan Hidup. Bina Hukum Lingkungan, 1, (2), 207-218. https://doi.org/10.24970/jbhl.v1n2.16

Mukhlish, M. (2010). Konsep Hukum Administrasi Lingkungan dalam Mewujudkan Pembangunan Berkelanjutan. Jurnal Konstitusi, 7, (2), 67-98.

Nasarudin, T. M. (2016). Asas dan Norma Hukum Administrasi Negara dalam Pembuatan Instrumen Pemerintahan. Jurnal Hukum Novelty, 7, (2), 139-154. https://doi.org/10.26555/novelty.v7i2.a5463

Ruslina, E. (2012). Makna Pasal 33 Undang-Undang Dasar 1945 dalam Pembangunan Hukum Ekonomi Indonesia. Jurnal Konstitusi, 9, (1), 49-82.

Syaprillah, A. (2016). Penegakan Hukum Administrasi Lingkungan Melalui Instrumen Pengawasan. Bina Hukum Lingkungan, 1, (1), 99-113. https://doi.org/10.24970/jbhl.v1n1.8

Thahira, A. (2020). Penegakan Hukum Administrasi Lingkungan Hidup Ditinjau dari Konsep Negara Hukum. JCH (Jurnal Cendekia Hukum), 5, (2), 260. https://doi.org/10.33760/jch.v5i2.229

Umam, S. (2017). Ekonomi Pancasila di Tengah Arus Kapitalisme Pasar. Tribakti: Jurnal Pemikiran Keislaman, 28, (2), 434459. https://doi.org/10.33367/tribakti.v28i2.491

Wijoyo, S. (2013). Pengkajian Hukum Tentang Perlindungan Kepada Masyarakat Dalam Sengketa Lingkungan Hidup. Jakarta: Kementerian Hukum dan Hak Asasi Manusia Republik Indonesia Badan Pembinaan Hukum NasionaL. https://bphn.go.id/data/documents/laphir_lingkungan_hidup.p df

\section{https://doi.org/10.6000/1929-4409.2021.10.109}

(C) 2021 Sugiharto et al.; Licensee Lifescience Global.

This is an open access article licensed under the terms of the Creative Commons Attribution Non-Commercial License (http://creativecommons.org/licenses/by-nc/3.0/) which permits unrestricted, non-commercial use, distribution and reproduction in any medium, provided the work is properly cited. 